\title{
Hubungan Asupan Zat Gizi Makro, Status Gizi dan Aktivitas Fisik Terhadap Tingkat Kebugaran pada Lansia di Kampung Jasugih Propinsi Banten
}

\author{
Evita Ellawati ${ }^{1}$, Yulia Wahyuni ${ }^{2}$, Mertien Sapang ${ }^{3}$ \\ ${ }^{1}$ Program Studi Gizi Fakultas Ilmu-Ilmu Kesehatan Universitas Esa Unggul \\ Jalan Arjuna Utara No.9 Kebon Jeruk Jakarta 11510 \\ Korespondensi e-mail: evitaaaa977@gmail.com \\ Submitted: 18 Oktober 2020, Revised: 13 April , Accepted: 29 April 2021
}

\begin{abstract}
The elderly are vulnerable to health problems and nutritional problems. One of the health problems that occur in the elderly can be in the form of a decrease in physical fitness cused by a reduced number of cell in the body. The aim of this study was to evaluate the relationship between macro nutrient intake (energy, protein, fat, carbohydrate), nutritional status and physical activity on fitness level in the elderly in Jasugih village, Banten province. The study uses a quantitative approach with cross sectional design. The sample was taken using purposive sampling technique with a total sample of 44 elderly as respondents. Bivariate analysis was used Fisher's exact test. The results showed that the average age of the respondents in the Jasugih village Banten province is 65-80 years. Based on the results of the Fisher exact test, it shows that there was a significant relationship between energy intake and fitness level $(p=0.037)$, there was no significant relationship between protein intake an fitness level $(p=0.554)$, there was significant relationship between fat intake and fitness level $(p=0.033)$, there was significant relationship between carbobydrate intake and fitness level $(p=0.034)$, there was no significant relationship between nutritional status and fitness level $(p=1.000)$, there was significant relationship between physical activity and fitness level $(p<0.05)$. In conclusion, Energy intake especially from fats and carbobydrates associated with fitness level significantly. Elderly should consume adequate energy intake to fulfill their fitness.
\end{abstract}

Keyword: Elderly, Macro Nutrient Intake, Nutritional Status, Physical Fitness

\begin{abstract}
Abstrak
Lansia sangat rentan terhadap masalah kesehatan maupun masalah gizi. Masalah kesehatan yang terjadi pada lansia salah satunya dapat berupa penurunan kebugaran jasmani yang disebabkan berkurangnya jumlah sel-sel yang ada di dalam tubuh. Tujuan dari penelitian ini yaitu menganalisis hubungan asupan zat gizi makro (energi, protein, lemak, karbohidrat), status gizi dan aktivitas fisik terhadap tingkat kebugaran pada lansia di kampung Jasugih provinsi Banten. Metode yang digunakan dalam penelitian ini adalah menggunakan pendekatan kuantitatif dengan desain Cross Sectional. Pengambilan sampel menggunakan teknik purposive sampling dengan total sampel sebanyak 44 lansia sebagai responden, analisis bivariat menggunakan uji statistik Fisher (Fisher Exact Test). Hasil penelitian menunjukkan rata-rata usia responden dikampung Jasugih Propinsi banten adalah 65-80 tahun. Berdasarkan hasil uji Fisher menunjukkan ada hubungan signifikan antara asupan energi dengan tingkat kebugaran $(p=0.037)$, tidak ada hubungan antara asupan protein dengan tingkat kebugaran $(\mathrm{p}=0.554)$, ada hubungan antara asupan lemak dengan tingkat kebugaran $(p=0.033)$, ada hubungan antara asupan karbohidrat dengan tingkat kebugaran $(p=0.034)$, tidak ada hubungan antara status gizi dan tingkat kebugaran $(\mathrm{p}=1.000)$, ada hubungan antara aktivitas fisik dan tingkat kebugaran $(\mathrm{p}<0.05)$. Kesimpulannya terdapat hubungan antara asupan energi dengan tingkat kebugaran, tidak terdapat hubungan antara asupan protein dengan tingkat kebugaran, terdapat hubungan antara asupan lemak dengan tingkat kebugaran, terdapat hubungan antara asupan karbohidrat dengan tingkat kebugaran, tidak terdapat hubungan antara status gizi dengan tingkat kebugaran, terdapat hubungan antara aktivitas fisik dengan tingkat kebugaran.
\end{abstract}

Kata Kunci: Lansia, Asupan Zat Gizi Makro, Status Gizi, Aktivitas Fisik, Tingkat Kebugaran

\section{Pendahuluan}

Lansia mengalami penurunan fungsi dan kinerja organ atau penuaan. Kondisi ini sangat dipengaruhi oleh gaya hidup dan juga genetik (1). Penuaan adalah proses biologis normal pada manusia meliputi perubahan yang berangsur-angsur, mulai dari struktur, fungsi dan toleransi tubuh terhadap stress lingkungan. Penuaan selalu selaras dengan waktu karena merupakan periode yang tidak bisa diulang dan

Nutrire Diaita Vol.13, No.01, April 2021 ,p. 07-14 
bersifat universal (2). Penuaan masuk ke alur tahapan akhir pada lansia dan dianggap sebagai hal yang mutlak namun tidak selalu mengalami kerusakan fungsi organ atau penyakit (3). Menua merupakan hal alamiah yang tidak bisa dihindari sehingga menurunnya tingkat ketahanan tubuh harus diimbangi dengan olahraga kesehatan.

Olahraga kesehatan merupakan olahraga yang bertujuan dan bersifat optimal untuk kesehatan, yang bisa dilakukan semua golongan baik dari anak-anak hingga lansia. Olahraga kesehatan diperlukan untuk menjaga kesehatan dan kebugaran setiap harinya, karena sehat merupakan landasan tercapainya kesejahteraan hidup manusia. Selain itu, aktivitas fisik membantu memperbaiki kebugaran lansia yang mengalami penurunan fungsi tubuh (4). Aktivitas fisik dan partisipasi latihan aktif mempunyai manfaat yang baik untuk kesehatan (5). Olahraga merupakan suatu kebutuhan penting bagi tubuh, selain itu dengan rutinnya berolahraga yang terukur dapat menghindarkan dari sejumlah penyakit.

Kebugaran merupakan salah satu tolak ukur kesehatan masyarakat termasuk pada lansia. Lansia yang memiliki kebugaran yang tinggi selain sehat dan segar juga dapat melakukan berbagai aktivitas secara mandiri di kesehariannya. Sebaliknya, kebugaran yang buruk pada lansia tidak jarang membuat lansia terlihat tidak sehat (6). Permasalahan kesehatan maupun kebugaran pada lansia tentunya berkaitan dengan kebutuhan gizi yang adekuat (7). Pola makan yang baik sangat dibutuhkan yaitu dengan mengkonsumsi makronutrien yang terdiri dari energi, protein, lemak dan karbohidrat secara seimbang, yaitu dengan presentase karbohidrat $55-60 \%$ serta presentase yang sama pada protein dan lemak yaitu 20-25\% (8). Asupan makanan pada lansia sebaiknya tidak berlebihan atau kurang, waktu makan teratur sesuai dengan dan jenis makanan yang sesuai agar tidak mengabaikan manfaat dan kandungan gizinya (9). Upaya lansia agar menjaga kesehatan serta kebugaran tidak akan menjadi beban bagi orang lain merupakan hal yang penting karena dikhawatirkan aktivitas fisik yang sudah menurun pada lansia dapat menimbulkan permasalahan tidak hanya pada kebugaran, namun juga pada status gizi lansia, yakni kekurangan gizi dikarenakan menurunnya nafsu makan akibat penyakit yang dideritanya, kesulitan menelan karena berkurangnya air liur, cara makan yang lambat karena penyakit pada gigi.

Kebugaran dapat dinilai dari empat bidang utama yaitu: kebugaran aerobik, kebugaran otot, fleksibilitas dan komposisi tubuh (10). Kebugaran aerobik maupun kebugaran pada lansia dapat dilakukan salah satunya dengan mengukur jarak yang ditempuh pada tes jalan 6 menit yang merupakan fitness test lansia yang dirancang untuk menguji kebugaran, ini merupakan sebuah adaptasi dari tes lari 12 menit Cooper (11). Lansia dikampung Jasugih cukup energik serta memiliki penampilan fisik terlihat bugar. Meskipun sudah lanjut usia, akan tetapi mereka masih mampu melakukan pekerjaannya sehari-hari tanpa bergantung kepada orang lain namun lansia disana cenderung memiliki aktivitas yang homoge seperti istirahat, makan, mengaji dan berkebun.

\section{Metode Penelitian}

Penelitian ini dilakukan oleh lansia dikampung Jasugih provinsi Banten. Penelitian ini dilaksanakan pada bulan Juni - Juli 2020, yang meliputi pengambilan data, analisis data dan penyusunan laporan. Data penelitian ini bersumber dari data primer dari hasil turun lapang di Kampung Jasugih, Provinsi Banten. Pada penelitian ini biasanya meliputi gambaran umum, lokasi penelitian, jumlah lansia. Penelitian ini dilakukan oleh lansia yang merupakan masyarakat kampung Jasugih Provinsi Banten. Perhitungan sampel didapatkan dari perhitungan rumus slovin yaitu sebanyak 44 lansia sebagai responden. Kriteria eksklusi pada penelitian ini adalah Lansia yang tidak bisa berkomunikasi dengan baik atau menurunnya fungsi kognitif serta lansia yang menderita gangguan mental atau gangguan jiwa. Pengukuran antropometri yaitu dengan melakukan pencatatan usia, penimbangan berat badan, pengukuran tinggi badan. Food Weigbing $2 \mathrm{x}$ 24 jam untuk pengukuran asupan zat gizi makro. Data status gizi diperoleh dengan mengukur berat badan dan tinggi badan responden dengan rumus $\mathrm{BB} / \mathrm{TB}^{2}$. Aktivitas fisik diperoleh dari hasil wawancara dengan responden menggunakan kuesioner Physical Activity Level (PAL) dan pengukuran tingkat kebugaran menggunakan tes jalan 6 menit (Six Minute Walking Test). Data yang terkumpul diolah dan dibentuk manajemen data. Pengolahan data menggunakan analisa kuantitatif dengan menggunakan perangkat lunak pada computer yaitu SPSS version 25 for Windows dan dianalisis secara univariat dan bivariat. Variabelvariabel yang dimasukkan kedalam data meliputi: usia, asupan zat gizi makro (energi, protein, lemak,

Nutrire Diaita Vol.13, No.01, April 2021 ,p. 07-14 
karbohidrat), status gizi, aktivitas fisik dan tingkat kebugaran. Penelitian ini juga telah lulus etik penelitian Universitas Esa Unggul dengan nomor 0260-20.227/DPKE-KEP/FINAL-EA/UEU/VIII/2020

\section{Hasil dan Pembahasan}

Jumlah sampel dalam penelitian ini sebanyak 44 lansia perempuan sebagai responden. Berdasarkan usia, jumlah responden terbanyak terdapat pada kelompok usia 65-80 tahun yaitu sebanyak $70.46 \%$. Usia merupakan salah satu faktor yang mempengaruhi kebugaran fisik. Semakin bertambahnya usia maka kebugaran fisik semakin menurun. Dari hasil pengukuran vo2max dengan tes jalan 6 menit (6MWT) dari 44 responden didapatkan hasil sebanyak 32 orang (72,73\%) memiliki kebugaran kurang dan sebanyak 12 orang $(27,27 \%)$ memiliki kebugaran baik. Itu artinya, mayoritas dari responden yang berusia 65-80 tahun memiliki presentase kebugaran kurang cukup besar yaitu $72.73 \%$. Kebugaran jasmani berkaitan dengan kondisi fisik seseorang dalam melaksanakan tugas sehari-hari secara efisien dalam waktu yang relatif lama tanpa mengalami kelelahan yang berarti dan masih memiliki cadangan tenaga untuk melakukan aktivitas lainnya. Kebugaran jasmani merupakan kemampuan yang dimiliki seseorang untuk melakukan suatu pekerjaan yang cukup berat dan cukup lama tanpa mengalami kelelahan yang berarti. Seseorang yang memiliki derajat kebugaran masih memiliki tenaga cadangan untuk menghadapi suatu pekerjaan atau keadaan yang mendesak. Kondisi sehat belum tentu memiliki kebugaran jasmani yang tinggi dan belum tentu dapat mengerjakan suatu pekerjaan atau olahraga yang cukup berat dan lama. Seseorang yang memiliki kebugaran bisa dipastikan sehat (12). Kebugaran tubuh seseorang tidak dapat dinilai dari penampilan fisik saja, namun juga dari pola hidup, pola makan dan aktivitas fisik.

\section{Gambaran Asupan Energi, Asupan Protein, Asupan Lemak, Asupan Karbohidrat, Status Gizi, Aktivitas Fisik dan Tingkat Kebugaran}

Tabel 2. menunjukkan bahwa berdasarkan asupan zat gizi makro dibagi dalam kategori kurang, cukup dan lebih. Berdasarkan asupan energi pada lansia di kampung Jasugih provinsi Banten menunjukkan bahwa didominasi oleh responden dalam kategori cukup yaitu sebanyak 36 responden (81,81\%), asupan protein didominasi dalam kategori kurang yaitu sebanyak 19 responden $(43,18 \%)$, asupan lemak didominasi dalam kategori cukup yaitu sebanyak 29 responden (65,90\%), asupan karbohidrat didominasi dalam kategori cukup yaitu sebanyak 30 responden (68,18\%). Status gizi didominasi dalam kategori normal yaitu sebanyak 32 responden (72,73\%). Aktivitas fisik dibagi kedalam kategori ringan, sedang, berat. Berdasarkan aktivitas fisik pada lansia di kampung Jasugih provinsi Banten menunjukkan bahwa di dominasi dalam kategori ringan yaitu sebanyak 26 responden (59,09\%). Tingkat kebugaran dibagi kedalam kategori kurang dan baik. Berdasarkan tingkat kebugaran pada lansia di kampung Jasugih provinsi Banten menunjukkan bahwa didominasi dalam kategori kurang yaitu sebanyak 32 responden $(72,73 \%)$.

Lansia merupakan dua kesatuan fakta sosial dan biologi. Sebagai suatu fakta sosial, lansia merupakan suatu proses penarikan diri seseorang dari berbagai status dalam suatu struktur masyarakat. Secara fisik, pertambahan usia dapat berarti semakin melemahnya manusia secara fisik dan kesehatan (13). Berdasarkan data yang diperoleh yaitu sebanyak 13 orang (29,54\%) lansia berusia antara 50-64 tahun dan sebanyak 31 orang $(70,46 \%)$ lansia berusia antara 65-80 tahun. Asupan zat gizi makro yang dibutuhkan oleh lansia berbeda dengan yang dibutuhkan oleh orang dewasa karena perbedaan aktivitas fisik yang dilakukan. Selain itu, zat gizi yang dibutuhkan oleh lansia untuk menjaga sel-sel maupun organ-organ dalam tubuh agar bisa tetap bisa berfungsi dengan baik walaupun fungsinya tidak sebaik ketika muda. Oleh karena itu, mengatur pola makan setelah berusia 40 tahun ke atas menjadi sangat penting (14). Perubahan fisiologi yang berhubungan dengan aspek gizi pada lansia adalah semakin berkurangnya indera penciuman dan perasa yang pada umumnya membuat lansia kurang dapat menikmati makanan dengan baik. Hal ini membuat aktivitas makan menjadi kurang bagi lansia, sehingga asupan gizi semakin berkurang (14). Asupan energi pada lansia di Kampung Jasugih Provinsi Banten adalah sebanyak 6 orang (13,63\%) memiliki asupan energi kurang, sebanyak 36 orang $(81,81 \%)$ memiliki asupan energi cukup dan sebanyak 2 orang $(4,54 \%)$ memiliki asupan energi berlebih. Asupan protein pada lansia sebanyak 19 orang (43,18\%) memiliki asupan protein kurang, sebanyak 17 orang $(38,63 \%)$ memiliki asupan protein cukup dan sebanyak 8 orang $(18,18 \%)$ memiliki asupan protein berlebih. Asupan lemak pada lansia sebanyak 12 orang $(27,27 \%)$

Nutrire Diaita Vol.13, No.01, April 2021 ,p. 07-14 
memiliki asupan lemak kurang, sebanyak 29 orang $(65,90 \%)$ memiliki asupan lemak cukup dan sebanyak 3 orang $(6,81 \%)$ memiliki asupan lemak berlebih.

Tabel 2.

Distribusi Asupan Energi, Asupan Protein, Asupan Lemak, Asupan Karbohidrat, Status Gizi, Aktivitas Fisik danTingkat Kebugaran Lansia

\begin{tabular}{cccc}
\hline Variabel & Kategori & $\mathbf{n}$ & $\mathbf{0}$ \\
\hline \multirow{3}{*}{ Asupan Energi } & Kurang & 6 & 13,63 \\
& Cukup & 36 & 81,81 \\
& Lebih & 2 & 4,54 \\
\hline \multirow{2}{*}{ Asupan Protein } & Kurang & 19 & 43,18 \\
& Cukup & 17 & 38,63 \\
& Lebih & 8 & 18,18 \\
\hline \multirow{2}{*}{ Asupan Lemak } & Kurang & 12 & 27,27 \\
& Cukup & 29 & 65,90 \\
Asupan Karbohidrat & Lebih & 3 & 6,81 \\
\hline \multirow{2}{*}{ Status Gizi } & Kurang & 12 & 27,27 \\
& Cukup & 30 & 68,18 \\
& Lebih & 2 & 4,54 \\
\hline \multirow{2}{*}{ Akivitas Fisik } & Kurang & 4,09 \\
& Normal & 32 & 72,73 \\
& Lebih & 8 & 18,18 \\
\hline \multirow{2}{*}{ Tingkat Kebugaran } & Ringan & 59,09 \\
& Sedang & Berat & 36,36 \\
& Kurang & 4,55 \\
\hline
\end{tabular}

Sumber: Data Primer

Asupan karbohidrat pada lansia sebanyak 12 orang (27,27\%) memiliki asupan karbohidrat kurang, sebanyak 30 orang $(68,18 \%)$ memiliki asupan karbohidrat cukup dan sebanyak 2 orang (4,54\%) memiliki asupan karbohidrat berlebih.

Status gizi dan status kesehatan yang baik akan membawa seseorang kepada umur panjang yang sehat dan produktif. Selain itu, status kesehatan lansia akan berpengaruh dalam penilaian kebutuhan akan zat gizi (15). Status gizi merupakan keadaan akibat keseimbangan antara konsumsi, penyerapan dan penggunaan zat gizi (16). Pada lansia di kampung Jasugih Provinsi Banten sebanyak 4 orang (9,09\%) memiliki status gizi kurang, sebanyak 32 orang $(72,73 \%)$ memiliki status gizi normal dan sebanyak 8 orang $(18,18 \%)$ memiliki status gizi berlebih. Dengan nilai rata-rata status gizi $22.48 \pm 4.327 \mathrm{~kg} / \mathrm{m}^{2}$. Salah satu faktor predisposisi penurunan kebugaran adalah kurangnya aktivitas fisik. Setiap tahun jumlah lansia di Indonesia yang mengalami keterbatasan melakukan aktivitas fisik terus meningkat (14). Oleh karena itu, aktivitas fisik dan olahraga yang sesuai dengan kondisi fisik lansia dan dilakukan secara teratur sangat dibutuhkan (17). Dari hasil pengukuran aktivitas fisik melalui wawancara serta pengisian kuesioner Physical Activity Level (PAL) 2 × 24 jam didapatkan bahwa sebanyak 26 orang $(59,09 \%)$ memiliki aktivitas fisik ringan, sebanyak 16 orang $(36,36 \%)$ memiliki aktivitas fisik sedang dan sebanyak 2 orang $(4,55 \%)$ memiliki aktivitas fisik berat. 
Tabel 3.

Analisis Hubungan Asupan Energi, Asupan Protein, Asupan Lemak, Asupan Karbohidrat, Status Gizi dan Aktivitas Fisik terhadap Tingkat Kebugaran pada Lansia

\begin{tabular}{|c|c|c|c|c|c|c|c|c|}
\hline & \multirow{3}{*}{ kategori } & \multicolumn{4}{|c|}{ Tingkat Kebugaran } & \multirow{2}{*}{\multicolumn{2}{|c|}{ Total }} & \multirow{3}{*}{$P$-value } \\
\hline & & \multicolumn{2}{|c|}{ Kurang } & \multicolumn{2}{|c|}{ Baik } & & & \\
\hline & & $\mathrm{n}$ & $\%$ & $\mathbf{n}$ & $\%$ & $\mathrm{n}$ & $\%$ & \\
\hline \multirow{3}{*}{ Asupan Energi } & Kurang & 4.4 & 10 & 1.6 & 3.63 & 6.0 & 100 & \\
\hline & Cukup & 26.2 & 59.54 & 9.8 & 22.27 & 36.0 & 100 & 0.037 \\
\hline & Lebih & 1.5 & 3.40 & 0.5 & 1.13 & 2.0 & 100 & \\
\hline \multirow{3}{*}{ Asupan Protein } & Kurang & 13.8 & 31.36 & 5.2 & 11.81 & 19 & 100 & \\
\hline & Cukup & 12.4 & 28.18 & 4.6 & 10.45 & 17 & 100 & 0.554 \\
\hline & Lebih & 5.8 & 13.18 & 2.2 & 5 & 8 & 100 & \\
\hline \multirow{3}{*}{ Asupan Lemak } & Kurang & 8.7 & 19.77 & 3.3 & 7.5 & 12 & 100 & 0.033 \\
\hline & Cukup & 21.1 & 47.95 & 7.9 & 17.95 & 29 & 100 & \\
\hline & Lebih & 2.2 & 5 & 0.8 & 1.81 & 3 & 100 & \\
\hline \multirow{3}{*}{$\begin{array}{c}\text { Asupan } \\
\text { Karbohidrat }\end{array}$} & Kurang & 8.7 & 19.77 & 3.3 & 7.5 & 12 & 100 & \\
\hline & Cukup & 21.8 & 49.54 & 8.2 & 18.63 & 30 & 100 & 0.034 \\
\hline & Lebih & 1.5 & 3.40 & 0.5 & 1.13 & 2 & 100 & \\
\hline \multirow{3}{*}{ Status Gizi } & Kurang & 2.9 & 6.59 & 1.1 & 2.5 & 4 & 100 & \\
\hline & Normal & 23.3 & 52.95 & 8.7 & 19.77 & 32 & 100 & 1.000 \\
\hline & Lebih & 5.8 & 13.8 & 2.2 & 5 & 8 & 100 & \\
\hline \multirow[t]{3}{*}{ Aktivitas Fisik } & Ringan & 18.9 & 42.95 & 7.1 & 16.13 & 26 & 100 & 0.000 \\
\hline & Sedang & 11.6 & 26.36 & 4.4 & 10 & 16 & 100 & \\
\hline & Berat & 1.5 & 3.40 & 0.5 & 1.13 & 2 & 100 & \\
\hline
\end{tabular}

\section{Hubungan Asupan Zat Gizi Makro dengan Tingkat Kebugaran}

Hasil analysis bivariate menunjukkan bahwa ada hubungan antara asupan energi dengan tingkat kebugaran pada lansia di kampung Jasugih provinsi Banten. Penelitian ini sejalan dengan teori Almatsier (2009) bahwa makanan sehari-hari yang dipilih dengan baik akan memberikan semua zat gizi yang dibutuhkan untuk fungsi normal tubuh yaitu terdiri dari karbohidrat, protein, lemak (18). Adapun fungsi zat makanan adalah sebagai sumber energi, mengatur metabolisme dan mengatur keseimbangan dan pertahanan tubuh terhadap berbagai penyakit. Sedangkan menurut penelitian yang dilakukan oleh Nurjannah (2018) bahwa tidak ada hubungan antara tingkat kecukupan energi dengan kebugaran, dimana kedua variabel tersebut menunjukkan tidak ada hubungan dengan nilai $\mathrm{p}=0.361$ serta nilai koefisien korelasi $\mathrm{r}=-0.143$ yang memiliki arti hubungan yang berlawanan dimana pada penelitian tersebut ditemukan responden dengan tingkat kecukupan energi yang tinggi atau identik dengan berbadan gemuk tidak dapat mencapai jarak tempuh $>500$ meter dalam waktu 6 menit (19).

Energi dibutuhkan untuk mendukung pertumbuhan, perkembangan, aktivitas otot dan fungsi metabolisme lainnya, dan untuk memperbaiki kerusakan jaringan dan tulang disebabkan oleh karena sakit dan cidera. Kecukupan energi dapat dipenuhi dengan mengkonsumsi makanan sumber karbohidrat, protein dan lemak. Kecukupan energi seseorang ditandai oleh berat badan yang normal. Saat melakukan olahraga atau aktivitas fisik, tubuh membutuhkan energi, saat jenis aktivitas fisik yang dilakukan adalah aktivitas yang berat dan untuk memenuhi kebutuhan energi yang optimal seseorang butuh konsumsi makanan sebelumnya, dengan konsumsi makanan maka asupan energi dalam tubuh akan terpenuhi dan secara langsung akan meningkatkan kebugaran pada lansia. Lansia yang memiliki tingkat kebugaran yang tinggi selain sehat dan segar juga dapat melakukan berbagai aktivitas secara mandiri dikesehariannya. Sebaliknya, tingkat kebugaran yang buruk pada lansia tidak jarang membuat lansia terlihat tidak sehat (6). 
Namun demikian, untuk asupan protein tidak ada hubungan antara asupan protein dengan tingkat kebugaran pada lansia di kampung Jasugih provinsi Banten. Padahal beberapa penelitian menjelaskan seperti penelitian Sugiarto (2012), menunjukkan bahwa ada hubungan yang bermakna antara asupan protein dengan tingkat kebugaran dengan nilai $p=0.001<0.005(20)$. Hal tersebut berkaitan dengan fungsi protein yaitu membangun serta memelihara sel-sel dan jaringan tubuh. Protein dapat juga digunakan sebagai bahan bakar apabila keperluan energi tubuh tidak terpenuhi oleh karbohidrat dan lemak. Protein ikut mengatur berbagai proses tubuh, baik langsung maupun tidak langsung dengan membentuk zat-zat pengatur proses dalam tubuh (20). Yang menarik, penelitian Nurjannah (2018) menunjukkan bahwa terdapat hubungan diantara keduanya namun memiliki arah yang berlawanan, dimana responden dengan tingkat kecukupan protein yang kurang belum tentu tidak mampu menempuh jarak $>300$ meter dalam enam menit begitupun sebaliknya (19). Oleh karena itu, tentu diperlukan telaah lebih lanjut mengenai peranan protein dalam mempengaruhi kebugaran.

Untuk asupan lemak, menunjukkan bahwa ada hubungan antara asupan lemak dengan tingkat kebugaran pada lansia di kampung Jasugih provinsi Banten. Penelitian ini berbeda dengan penelitian yang dilakukan oleh Jati (2016) bahwa antar konsumsi energi, protein lemak, karbohidrat, kalsium, fosfor dan vitamin A dengan tingkat kebugaran Chair Stand dan 2-Minute Step, tidak memiliki hubungan yang signifikan $(\mathrm{p}>0.005)(21)$. Hasil ini menunjukkan bahwa faktor gizi bukanlah satu-satunya yang mempengaruhi tingkat kebugaran lansia, tetapi ada faktor-faktor lain diluar asupan makanan (energi dan zat gizi) yang dapat mempengaruhi tingkat kebugaran. Salah satu upaya untuk mendapatkan kebugaran jasmani yang baik diperlukan tingkat konsumsi zat gizi yang cukup sesuai dengan kebutuhannya (22). Sementara untuk karbohidrat, menunjukkan bahwa ada hubungan antara asupan karbohidrat dengan tingkat kebugaran pada lansia di kampung Jasugih provinsi Banten. Penelitian ini berbeda dengan penelitian yang dilakukan oleh Jati (2016) yang menunjukkan tidak ada hubungan signifikan antara konsumsi karbohidrat dengan tingkat kebugaran (21). Hasil ini menunjukkan bahwa faktor gizi bukanlah satu-satunya yang mempengaruhi tingkat kebugaran lansia, tetapi ada faktor-faktor lain diluar asupan makanan (energi dan zat gizi) yang dapat mempengaruhi tingkat kebugaran.

\section{Hubungan Status Gizi dengan Tingkat Kebugaran}

Untuk status gizi dan tingkat kebugaran menunjukkan hubungan yang tidak signifikan. Hasil penelitian ini sejalan dengan penelitian yang dilakukan oleh Jati (2016), bahwa status gizi dengan kebugaran menunjukkan hubungan yang tidak signifikan $(p>0,05)(21)$. Status gizi rendah belum tentu memiliki kebugaran yang rendah begitu pula sebaliknya. Kebugaran tidak sepenuhnya dipengaruhi oleh status gizi saja, tetapi juga aktivitas fisik yang dilakukan lansia. Selain itu, kebugaran dipengaruhi oleh beberapa faktor lain yaitu usia, jenis kelamin, genetik dan kebiasaan merokok (23). Penelitian ini juga sejalan dengan penelitian yang dilakukan oleh Camelia Nurjannah, dkk bahwa tidak terdapat hubungan antara IMT dengan kebugaran (19). Menurut Sugeng (2007), kebugaran tubuh tidak hanya dipengaruhi oleh faktor status gizi, namun juga dipengaruhi oleh faktor genetik, faktor intensitas latihan, usia, jenis kelamin dan kebiasaan merokok (24). Namun demikian, hasil penelitian ini berbeda dengan penelitian Putu Zelvya (2014) yang menunjukkan bahwa terdapat hubungan positif yang kuat antara status gizi dengan kebugaran lansia (10). Menurut Nurhasan (2005) bahwa status gizi merupakan keadaan gizi pada seseorang dan juga pada sekelompok masyarakat dengan memperhitungkan zat-zat gizi yang diperoleh dari makanan sehari-hari (25). Selain itu status gizi akan mencerminkan kualitas fisik yang rendah dan akan berdampak pada tingkat kebugaran jasmani yang berakibat terhadap rendahnya kemampuan kerja.

\section{Hubungan Aktivitas Fisik dengan Tingkat Kebugaran}

Penelitian kami menunjukkan ada hubungan antara aktivitas fisik dengan tingkat kebugaran pada lansia di kampung Jasugih provinsi Banten. Aktivitas fisik yang baik untuk lansia adalah aktivitas fisik yang tidak terlalu berat, seperti jalan kaki, senam, dll (26). Lansia yang bugar memiliki tingkat aktivitas fisik lebih banyak dibandingkan dengan lansia yang tidak bugar. Aktivitas fisik adalah salah satu yang berpengaruh pada kebugaran, dimana aktivitas fisik menurut WHO adalah gerakan tubuh yang dihasilkan oleh otot rangka yang membutuhkan pengeluaran energi (27). 


\section{Kesimpulan}

Di Kampung Jasugih Provinsi Banten menunjukkan proporsi sebagian besar usia lansia 65-80 tahun. Status gizi, onsumsi energy dan karbohidrat mempengaruhi kebugaran lansia di Kampung Jasugih Banten. Sementara status gizi, konsumsi protein dan lemak tidak mempengaruhi kebugaran lansia di Kampung Jasugih. Aktivitas fisik juga mempengaruhi kebugaran lansia. Oleh karena itu, lansia di Kampung Jasugi Banten sebaiknya mampu menuckupi konsumsi energy dan karbohidrat serta melakukan aktivitas fisik sesuai kapasitas untuk menunjang kebugaran.

\section{Daftar Pustaka}

1. Garatachea N, Lucia A. Genes, Physical Fitness and Ageing. Ageing Res Rev. 2013;12(1):90-102. Available from: http://dx.doi.org/10.1016/j.arr.2012.09.003.

2. Latorre-Rojas E-J, Prat-Subirana J-A, Peirau-Terés X, Mas-Alòs S, Beltrán-Garrido J-V, PlanasAnzano A. Determination Of Functional Fitness Age In Women Aged 50 And Older. J Sport Heal Sci. 2017;8(3):267-72. Available from: http://dx.doi.org/10.1016/j.jshs.2017.01.010.

3. Munawwarah M, Nindya P. Pemberian Latiban Pada Lansia Dapat Meningkatkan Keseimbangan dan Mengurangi Resiko Jatuh Lansia. Fak Fisioter Univ Esa Unggul. 2015;15(April):38-44. Available from: http://ejurnal.stikesbaptis.ac.id/index.php/STIKES/article/view/306/279.

4. Guidetti L, Franciosi E, Gallotta M-C, Emerenziani G-P, Baldari C. Could Sport Specialization Influence Fitness and Health Of Adults With Mental Retardation? Res Dev Disabil. 2010;31(5):1070-5.

5. K. Sultoni, Jajat M-F. Health-Related Fitness Knowledge and Its Relation to Collage Student Physical Activity Health-Related Fitness Knowledge and Its Relation to Collage Student Physical Activity. I O P Conf 2017 180, 8-12. 2017; doi:10.1088/1757-899X/180/1/012212.

6. Rosmalina Y, Permaesih D, Emawati F, Christiani R, Moeloek D, Herman S. Faktor-Faktor Yang Berbubungan Dengan Tingkat Kesegaran Jasmani Lansia Laki-Laki Tidak. Anemia. J Penelit Gizi dan Makanan. 2003;26(1):11-20. Available from: http:// journal.litbang.depkes.go.id/index.php/pgm/article/view/1426/2971.

7. Ismayanti N, Solikhah. Hubungan Antara Pola Konsumsi Dan Aktivitas Fisik. Dengan Status Gizi Pada Lansia Di Panti Sosial Tresna Werdha Unit Abiyoso Yogyakarta. J Kesehat Masy (Journal Public Heal. 2013;6(3).

8. Arisman. Gizi Dalam Daur Kehidupan. Jakarta: Penerbit Buku Kedokteran.EGC; 2010.

9. Rian. Pengaruh Faktor Motivasi diri, Perasaan dan Emosi serta Dukungan Keluarga Terbadap Pola Makan di UPT Pelayanan Sosial Lanjut Usia Binjai. Univ Sumatera Utara. 2012.

10. Zelvya P-V-A. Hubungan Status Gizi Terbadap Kebugaran Lansia di Paguyuban Senam Karang Weda Jambangan Surabaya. J Kesehat Olahraga. 2014;2(2):1-8.

11. Ghomim S. Hubungan Antara Kebugaran (Six minutes Walking Test) dengan Aktivitas Fisik, Status Giri, Asupan Nutrisi, Status Kesehatan dan Perilaku Merokok Pada Calon Jamaah Haji di Desa Mojosari. Univ Islam Negeri Syarif Hidayatullah. 2017.

12. Eli Maryani dan Jaja Suharja Husdarta. Praktik Belajar Pendidikan Jasmani, Olabraga dan Kesehatan. Jakarta: Pusat Perbukuan Kementerian Pendidikan Nasional Tahun 2010; 2010.

13. Prayitno S. Penduduk Lanjut Usia. Bandung. Universitas Pendidikan Indonesia. 1999.

14. Fatmah. Gizi Usia Lanjut. Jakarta: Penerbit Erlangga; 2010.

15. Arisman. Gizi dalam Daur Kebidupan. Jakarta: EGC; 2004.

16. Supariasa I-D-N. Pendidikan dan Konsultasi Gizi. Jakarta: EGC; 2012.

17. Trihandini I. Peran Medical Check-up Terhadap Aktivitas Fisik Dasar Lansia: Studi Panel Kelompok Lanjut Usia. Makara. Kesehatan 2007; 11 (2)90-96. 2007.

18. Almatsier S. Prinsip Dasar Ilmu Giži. Jakarta: PT Gramedia Pustaka Utama; 2009.

19. Nurjannah C, Rahfiludin M-Z, Kartini A. Hubungan Asupan Makeronutrien, Indeks Massa Tubuh (IMT) dan Aktivitas Fisik dengan Kesegaran Jasmani Pada Lansia. J Kesehat Masy. 2018;6(5):317-25.

20. Sugiarto. Hubungan Asupan Energi, Protein dan Suplemen dengan Tingkat Kebugaran. J Media Ilmu Keolahragaan Indonesia. 2012.

21. Jati A-S-E. Hubungan Konsumsi Pangan dan Aktivitas Fisik Dengan Status Gizi Serta Tingkat Kebugaran Lansia Peserta Pusaka V Jakarta Pusat. Bogor: Fakultas Ekologi Manusia Universitas 
Pertanian Bogor. 2016.

22. Sumintarsih. Kebugaran Jasmani untuk Lanjut Usia. Yogyakarta: UPN "Veteran"; 2016.

23. Fatmah. Gizi Usia Lanjut. Jakarta: Penerbit Erlangga; 2011.

24. Sugeng R. Keperawatan Kesehatan Masyarakat. Jakarta: Salemba Medika; 2007.

25. Nurhasan dkk. Petunjuk Praktis Pendidikan Jasmani. Surabaya: Unesa University; 2005.

26. Junaidi S. Pembinaan Fisik Lansia melalui Aktivitas Olahraga Jalan Kaki. Media Ilmu Keolahragaan Indonesia. 2011;1(1).

27. WHO. Definition Physical Activity. Geneva: World Health Organization. 2016. 